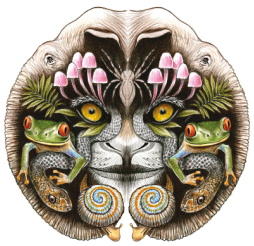

ISSN

Online 0974-7907

Print 0974-7893

OPEN ACCESS

\title{
MORPHOLOGICAL AND MOLECULAR IDENTIFICATION OF ACRIDID GRASSHOPPERS (ACRIDIDAE: ORTHOPTERA) FROM POONCH DIVISION, AZAD JAMMU KASHMIR, PAKISTAN
}

\author{
Naila Nazir ${ }^{1}$, Khalid Mehmood ${ }^{2}$, Muhammad Ashfaq ${ }^{3}$ \& Junaid Rahim ${ }^{4}$ \\ ${ }^{1,2,4}$ Department of Entomology, University of Poonch, Rawalakot, Azad Jammu Kashmir 12350, Pakistan \\ ${ }^{3}$ Biodiversity Institute of Ontario, University of Guelph, Ontario, Canada, N1G 2W1 \\ ${ }^{1}$ nzbsc_127@yahoo.com (corresponding author), ${ }^{2}$ kmmaldial@yahoo.com, ${ }^{3}$ muhammadashfaq@hotmail.com,
}

4junaidrahim47@yahoo.com

\begin{abstract}
The present study was conducted to resolve conflicts in the identification of grasshopper species of the family Acrididae (Orthoptera) on the basis of morphology and DNA barcoding. Grasshoppers representing 26 species of the family Acrididae were collected from different habitats and host plants from Poonch division of Azad Jammu Kashmir, Pakistan. Specimens were identified taxonomically and DNA sequenced for the cytochrome c oxidase (COI) barcode region. Barcodes of 19 morphological species were successfully obtained and the sequence data was used to separate species by Neighbor-Joining cluster analysis. Barcode data successfully discriminated 18 species, while two: Patanga japonica (Bolivar, 1898) and P. succincta (Johannson, 1763) could not be distinguished since they shared the barcode sequence and clustered together on the Neighbor-Joining (NJ) tree. Morphologically, specimens of Shirakiacris shirakii (Bolívar, 1914) were identified as one species, but barcode data revealed that in addition to Shirakiacris shirakii (Bolívar, 1914) two other species of the genus Shirakiacris are present in the region. Similarly, on the basis of morphological characters two species were indentified in subfamily Catantopinae, Catantops erubescens (Walker, 1870) and Xenocatantops brachycerus (Willemse, 1932), but barcode data suggest the presence of an additional Catantops species in the region. These findings show the usefulness of barcode data in discriminating grasshopper species and indicate that such data can be reliably used for developing reference libraries for species identification via sequence matches.
\end{abstract}

Keywords: Acrididae, COI, DNA barcoding, Kashmir, morphological identification.

DOI: http://dx.doi.org/10.11609/JoTT.o3507.5544-52| ZooBank: urn:Isid:zoobank.org:pub:32A15DA6-57FD-422D-9655-A467AA4E40B0

Editor: R.K. Avasthi, Rohtak University, Haryana, India.

Date of publication: 26 March 2014 (online \& print)

Manuscript details: Ms \# 03507 | Received 29 January 2013 | Final received 15 March 2014 | Finally accepted 18 March 2014

Citation: Nazir, N., K. Mehmood, M. Ashfaq \& J. Rahim (2014). Morphological and molecular identification of acridid grasshoppers (Acrididae: Orthoptera) from Poonch division, Azad Jammu Kashmir, Pakistan. Journal of Threatened Taxa 6(3): 5544-5552; http://dx.doi.org/10.11609/JoTT.o3507.5544-52

Copyright: (c) Nazir et al. 2014. Creative Commons Attribution 3.0 Unported License. JoTT allows unrestricted use of this article in any medium, reproduction and distribution by providing adequate credit to the authors and the source of publication.

Funding: Sequence analysis was made possible by a grant from Genome Canada and the Ontario Genomics Institute in support of the International Barcode of Life Project. Financial support was also provided by Higher Education Commission Pakistan by grant HEC No. 20-1403/R\& D/09.

Competing Interest: The authors declare no competing interests.

Author Contribution and Details: NAILA NAZIR - The principle author, it was her MSC (Hons.) research work. Now she is working as a lecturer. KHALID MAHMOOD - chairman and supervisor during the study. He is an orthopterist and currently working on some genera of Acrididae. MUHAMMAD ASHFAQ - CO-Supervisor, he was working as foreign professor in NIBGE Faislabad, Pakistan. His research interests are molecular biology and DNA barcoding of arthropods. He contributed in planning, carrying out the study and analyzing the sequence data. JUNAID RAHIM - assisted during the research in all aspects.

Acknowledgements: First author is greatly thankful to Insect Molecular Lab NIBGE (National Institute of Biotechnology and Genetic Engineering) Faislabad for providing me research facilities all those people (Sleem Akhter, Maryum Masood, Romana Ifthkar) there assisted me during my work. I would like to offer great sense of gratitude towards Biodiversity Institute of Ontario, University of Guelph, Canada for providing me facilities for DNA barcoding. My sincere thanks Prof. Dr. M. Rafique Khan for support, Prof Dr. M. Rahim Khan, Miss Ansa Tamkeen, Mr. Abdul Ghaffar, Shumila Arif, Munazza Khurshid for their assistance during my research work. I am greatly indebted to Mr Junaid Rahim for all sort of assistance during my research work and moral support. Support from Dr. Paul Hebert, Scientific Director of $\mathrm{BBOL}$ is acknowledged.
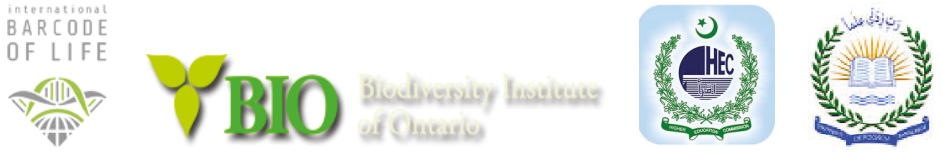


\section{INTRODUCTION}

Grasshoppers are the most prevalent pests in all sorts of vegetation in pastures and grasslands. Family Acrididae encompasses the short-horned grasshoppers and locusts, phytophagous insects that are widely distributed throughout the world and considered ruinous in the arid zone (Watts et al. 1982). Taxonomists generally use morphological identification for studies used to plan control strategies, but this method of identification has several limitations (Scotland et al. 2003). Cryptic species (sibling species) may be incorrectly identified due to phenotypic malleability. Morphologically enigmatic taxa are common in many groups neglected by this approach (Jarman \& Elliott 2000). Morphological keys are often limited to particular life stages, limiting the effectiveness of identification. Finally, a high level of proficiency is required to use the keys to avoid misdiagnoses. This has led to the use of molecular data to resolve cryptic species (Xiao et al. 2010). In micro genomic identification, system differences among DNA sequences are used to identify the different organisms (Wilson 1995). In fact these sequences are genetic barcodes enclosed in each cell. The barcode region, a 658-bp nucleotide fragment of mitochondrial COI has been accepted by scientists for identification of animal species (Hebert et al. 2003). The use of short standardized gene regions as internal species tag to recognize the species is an accurate, reliable, and rapid method. Due to copious benefits in identification, DNA barcoding is getting considerable concentration in the field of science (Hebert et al. 2004). The basic scientific advantage of DNA barcoding is fast and digital species identification at any life stage or piece of an organism, and the simplification of species explorations (Janzen et al. 2005). The selected DNA sequence precisely separates the species on the basis of interspecific and intraspecific variations (Matz \& Nielsen 2005). Barcoding has helped in resolving cryptic species complexes (Burns et al. 2007; Deng et al. 2012) and performing ecological studies on various animal phyla (Valentini et al. 2009). The generated data is also being used to construct barcode reference libraries for identification of unknowns by matching sequences with the known species (Guralnick \& Hill 2009; Janzen et al. 2009). A combination of molecular and morphological data can produce reliable data sets to be used in barcode libraries (Emery et al. 2009). Use of PCR as a tool to amplify and sequence genes and then exploit the nucleotide data for phylogenetic analysis and develop evolutionary relationships among grasshopper species has previously been practiced by a number of researchers
(Colgan 1991; Chapco \& Litzenberger 2003; Rowell \& Flook 2004). Several researchers have used DNA data in phylogenetic analysis to identify grasshopper species (Chapco \& Litzenberger 2002; Mukha et al. 2001; Song \& Wenzel (2007) Ketmaier et al. 2010). Use of DNA data has also been used in combination with morphological data to establish species relationships (Brust 2008).

Keeping in view the economic importance of grasshoppers and their damage to crops in Azad Kashmir, a need for correct identification of this group of pests has emerged. Azad Jammu \& Kashmir lies between $73-75^{\circ} \mathrm{N}$ and of $33-36^{\circ} \mathrm{E}$ and comprises an area of $5,134 \mathrm{~m}^{2}\left(13,297 \mathrm{~km}^{2}\right)$ (Fig. 1). Poonch division of Azad Jammu Kashmir comprises an area of $2,792 \mathrm{~km}^{2}$. Its topography is mainly hilly, climatic conditions and floristic composition significantly varies from place to place. Administratively, this division consists of four districts, Bagh, Poonch, Sudhnoti, and Haveli. A survey was conducted to identify grasshopper species of family Acrididae from Poonch division. Major contributions to the Acrididae fauna of Kashmir have been provided by some entomologists like Kirby (1914), Fletcher (1919), Mahmood (1995), Mahmood \& Yousaf (1999), Mahmood \& Yousaf (2000); Mahmood et al. (2002);

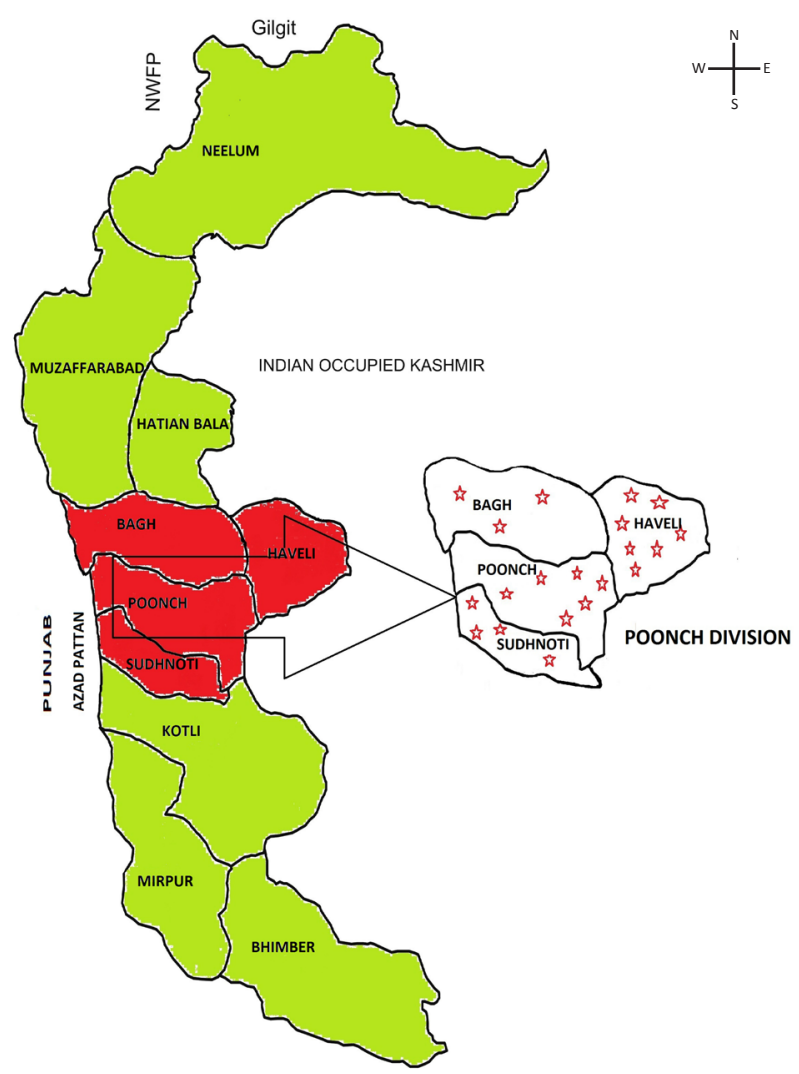

Figure 1. Map of Azad Kashmir illustrated Poonch division with highlighted collection localities 
Table 1. Characteristics of collection localities of study area

\begin{tabular}{|c|c|c|c|c|}
\hline District & Locality & Altitude(ft) & Latitude & Longitude \\
\hline \multirow{6}{*}{ Poonch } & Rawalakot & 5393 & $33.8^{\circ} \mathrm{N}$ & $73.8^{\circ} \mathrm{E}$ \\
\hline & Hajeera & 3167 & $33.6^{\circ} \mathrm{N}$ & $73.3^{\circ} \mathrm{E}$ \\
\hline & Jandali & 6785 & $33.3^{\circ} \mathrm{N}$ & $73.3^{\circ} \mathrm{E}$ \\
\hline & Banjosa & 6212 & $33.0^{\circ} \mathrm{N}$ & $73.9^{\circ} \mathrm{E}$ \\
\hline & Tolipeer & 8800 & $33.0^{\circ} \mathrm{N}$ & $73.9^{\circ} \mathrm{E}$ \\
\hline & Abbaspur & 4261 & $33.6^{\circ} \mathrm{N}$ & $73.0^{\circ} \mathrm{E}$ \\
\hline \multirow{4}{*}{ Sudhnoti } & Mang & 4842 & $33.2^{\circ} \mathrm{N}$ & $73.9^{\circ} \mathrm{E}$ \\
\hline & Plundari & 4000 & $33.2^{\circ} \mathrm{N}$ & $73.9^{\circ} \mathrm{E}$ \\
\hline & Baloch & 5304 & $33.8^{\circ} \mathrm{N}$ & $73.0^{\circ} \mathrm{E}$ \\
\hline & Trarkhel & 5600 & $33.9^{\circ} \mathrm{N}$ & $73.7^{\circ} \mathrm{E}$ \\
\hline \multirow{7}{*}{ Haveli } & Khautta & 5189 & $33.6^{\circ} \mathrm{N}$ & $74.5^{\circ} \mathrm{E}$ \\
\hline & Degwar & 5000 & $33.1^{\circ} \mathrm{N}$ & $74.4^{\circ} \mathrm{E}$ \\
\hline & Hajipeer & 8221 & $33.5^{\circ} \mathrm{N}$ & $74.9^{\circ} \mathrm{E}$ \\
\hline & Kalamola & 8207 & $33.3^{\circ} \mathrm{N}$ & $74.0^{\circ} \mathrm{E}$ \\
\hline & Aliabad & 8606 & $33.8^{\circ} \mathrm{N}$ & $73.1^{\circ} \mathrm{E}$ \\
\hline & Bedori & 12229 & $33.0^{\circ} \mathrm{N}$ & $74.9^{\circ} \mathrm{E}$ \\
\hline & Lasdana & 8069 & $33.5^{\circ} \mathrm{N}$ & $73.4^{\circ} \mathrm{E}$ \\
\hline \multirow{3}{*}{ Bagh } & Bagh City & 6000 & $33.8^{\circ} \mathrm{N}$ & $73.5^{\circ} \mathrm{E}$ \\
\hline & Dherkot & 5657 & $34.6^{\circ} \mathrm{N}$ & $73.3^{\circ} \mathrm{E}$ \\
\hline & Dhulli & 6082 & $33.6^{\circ} \mathrm{N}$ & $73.3^{\circ} \mathrm{E}$ \\
\hline
\end{tabular}

Mahmood \& Rizwan (2002); Mahmood \& Shah (2003) Mahmood et al. (2004); Reshi \& Azim (2008); Azim \& Reshi (2010) but nobody has made any effort to identify them on a molecular level either by DNA barcoding or by using any other marker. To remove identification conflicts among 26 morphological species of the family Acrididae from Poonch, and to add species sequences to the international barcode reference library, studies were performed to identify the grasshoppers morphologically and by DNA barcoding. Nevertheless, our knowledge of the grasshopper fauna of Azad Jammu Kashmir is still insufficient, particularly of species living in natural habitats and being commonly distributed over small areas.

\section{MATERIAL AND METHODS}

The collection of grasshoppers was carried out from the maximum floristic composition and cultivated crops like rice, maize, soybean, etc. A detailed survey of grasshoppers from the 19 localities of the study area (Table 1) from the year 2010-2011 and the collections were carried out with the help of a sweep net ( 24 inches diameter). The collected specimens were killed by cyanide and stretched out on the stretching board with the help of standard entomological pins (No. 16-40). The specimens were dried, examined with the use of a Leica MZ6 microscope and identified using keys (BieBienko \& Mischenko (1951), Drish (1961), Ritchie (1982), and Mason (1973), Suhail (1994), Mahmood (1995). The terminology of Kirby (1914) and Bie-Benko \& Mischenko (1951) were used in this identification process. The specimens of each identified species were confirmed from (Eades et al. 2011).

\section{Sequencing/ DNA barcoding}

Morphologically identified grasshopper specimens were transferred to the Insect Molecular Biology Lab, National Institute for Biotechnology and Genetic Engineering (NIBGE), Faisalabad for DNA barcoding for their identification at the molecular level. The specimens were processed following standard DNA barcoding protocols as outlined previously (Hebert et al. 2003). In brief, labeled specimens were arrayed in a 96-well PCR plate fashion to correspond with the location of tissue samples in the plates. Specimen data on field identification, taxonomic identification, identifier, voucher type, collectors, collection date, province, region, locality, latitude, longitude and elevation was entered on a spreadsheet. Specimen data and images were uploaded to the Barcode of Life Data System (BOLD) (www.boldsystems.org) hosted by the Biodiversity Institute of Ontario, University of Guelph, Canada. Tissue sampling was performed by removing a small part of the insect's leg and transferring it into the labeled 96 well PCR plate in the corresponding well. Six copies of each species were used for molecular studies.

\section{DNA isolation}

A small part of the leg from individual grasshoppers was transferred to the PCR plate and genomic DNA was extracted following protocols described by Ivanova et al. (2006) at the Canadian Centre for DNA Barcoding within the Biodiversity Institute of Ontario.

\section{PCR amplification and sequencing}

Amplification of the COI-5' (barcode) was performed with primer pair LCO1490_t1/ HCO2198_t1 (TGTAAAACGACGGCCAGTGGTCAACAAATCATAAAGATATTGG / CAGGAAACAGCTATGACTAAACTTCAGGGTGACCAAAAAATCA) following the PCR conditions; $94^{\circ} \mathrm{C}(1 \mathrm{~min})$, five cycles of $94^{\circ} \mathrm{C}(40 \mathrm{~s}), 45^{\circ} \mathrm{C}(40 \mathrm{~s}), 72^{\circ} \mathrm{C}(1 \mathrm{~min}) ; 35$ cycles of $94^{\circ} \mathrm{C}$ $(40 \mathrm{~s}), 51^{\circ} \mathrm{C}(40 \mathrm{~s}), 72^{\circ} \mathrm{C}(1 \mathrm{~min})$ and final extension of $72^{\circ} \mathrm{C}$ (5 min). PCRs were carried out in $12.5 \mu \mathrm{L}$ reactions containing standard PCR ingredients and $2 \mu \mathrm{L}$ of DNA 
template. PCR products were analyzed on $2 \%$ agarose E-gel $^{\circledR} 96$ system (Invitrogen Inc.). Amplicons were sequenced bidirectionally using the BigDye Terminator Cycle Sequencing Kit (Applied Biosystems) on an Applied Biosystems 3730XL DNA Analyzer. Sequences were assembled, aligned and edited using CodonCode Aligner (CodonCode Corporation, USA). Obtained barcode sequences were edited and analyzed and uploaded to the BOLD for further analysis and storage. Specimens used for tissue sampling were saved as voucher specimens for future reference.

\section{Sequence data analysis}

Sequence similarity analysis to determine the matching species in the DNA/barcode databases were performed by using "Blast" and "Identification Request" tools of the $\mathrm{NCBI}$ and BOLD. Currently barcodes of 3008 specimens representing 421 Acridid species are readily available on BOLD for sequence comparisons. ClustalW nucleotide sequence alignments (Thompson et al. 1994) were performed using MEGA V5 (Tamura et al. 2011) under default parameters. Patterns of sequence divergence among taxa were visualized using the neighbor-joining method (Thompson et al. 1994). Evolutionary distances were computed using the maximum composite likelihood method based upon the units of the number of base substitutions per site after all positions containing gaps and missing data were eliminated from the dataset (Complete deletion model). To perform pairwise distance analysis and to generate distance histograms and distance ranks we used an online version of Automatic Barcode Gap Discovery (ABGD) (Puillandre et al. 2012).

\section{RESULTS}

\section{Morphological identification and distribution of acridid species in Poonch}

Details of the specimen collection habitats and their host plants are outlined in Table 2 . The studies resulted in the morphological identification of 26 species under 15 genera of nine subfamilies of the family Acrididae (Table 2). Among subfamily Oedipodinae species of the genus Gastrimargus were found to be abundant at a higher altitude while Sphingonotus longipennis (Saussure, 1884), Aiolopus thalassinus tumulus (Fabricius, 1798), Trilophidia japonica (Sassure, 1888), Trilophidia turpis (Walker, 1870) were not abundant; only a few specimens of these species were collected during the survey. The species of genus Acrida of subfamily Acridinae were found to be abundant in areas of higher elevation while their population declined in lower elevations. Spathosternum parsiniferum parsiniferum (Walker, 1871) of subfamily Spathosterninae was found to be abundant at higher elevations while the species of genus Hieroglyphus, Hieroglyphus nigroreplatus (Bolivar, 1912), Hieroglyphus banian (Fabricius, 1798), Hieroglyphus concolar (Walker, 1870) and Hieroglyphus oryzivorus (Carl, 1916) were found on rice crops abundantly. Their population was restricted to lower elevations. While the species of subfamily Oxyinae particularly genus Oxya was recorded to be most abundant throughout the surveyed area, among them Oxya fuscovittata (Marschall, 1836) and $O$. hyla hyla (Serville, 1831) were most abundant over all sorts of vegetation. Subfamily Calliptaminae with the single species Acorypha glucopsis (Walker, 1870) was recorded as abundant at higher elevations. Eyprepocnemidinae also with the species Shirakiacris shirakii (Bolívar, 1914) and according to barcode results two more species (morphologically identified as Shirakiacris shirakii (Bolívar, 1914) but barcode results showed them to be different species under the same genus were found to be abundant at higher altitudes. The species of subfamily Catantopinae Pachyacris vinosa (Walker, 1870) was found to be very rich in higher altitudes and moderately in lower areas, while the population of Paraconophyma kashmiricum (Mischenko, 1950) was restricted only to the higher elevations of the surveyed area. The population of Catantops erubescens (Walker, 1870) and Xenocatantops brachycerus were not very plentiful but recorded from some higher areas from grasses, while Catantops innatobalis (Walker, 1871) was very rare with only a single specimen collected. Species of subfamily Cyrtacanthacridinae Patanga succincta (Johannson, 1763) and Patanga japonica (Bolivar, 1898) were most abundant in the surveyed area.

\section{Barcode analysis}

DNA barcodes of 85 specimens of 21 species were successfully sequenced and the size of the barcode was uniform among all the species producing successful barcodes. The sequences have either been allocated GenBank accession numbers or have been submitted to the European Molecular Biology Laboratory (EMBL)/ (DDBJ)/Gene Bank databases for assignment of accessions. We performed identity analysis of the species based on barcode sequence matches with those of other species already deposited in the Barcode of Life Data System (BOLD) and National Center for Biotechnology Information (NCBI) databases. From the database searches we found that only one species, 


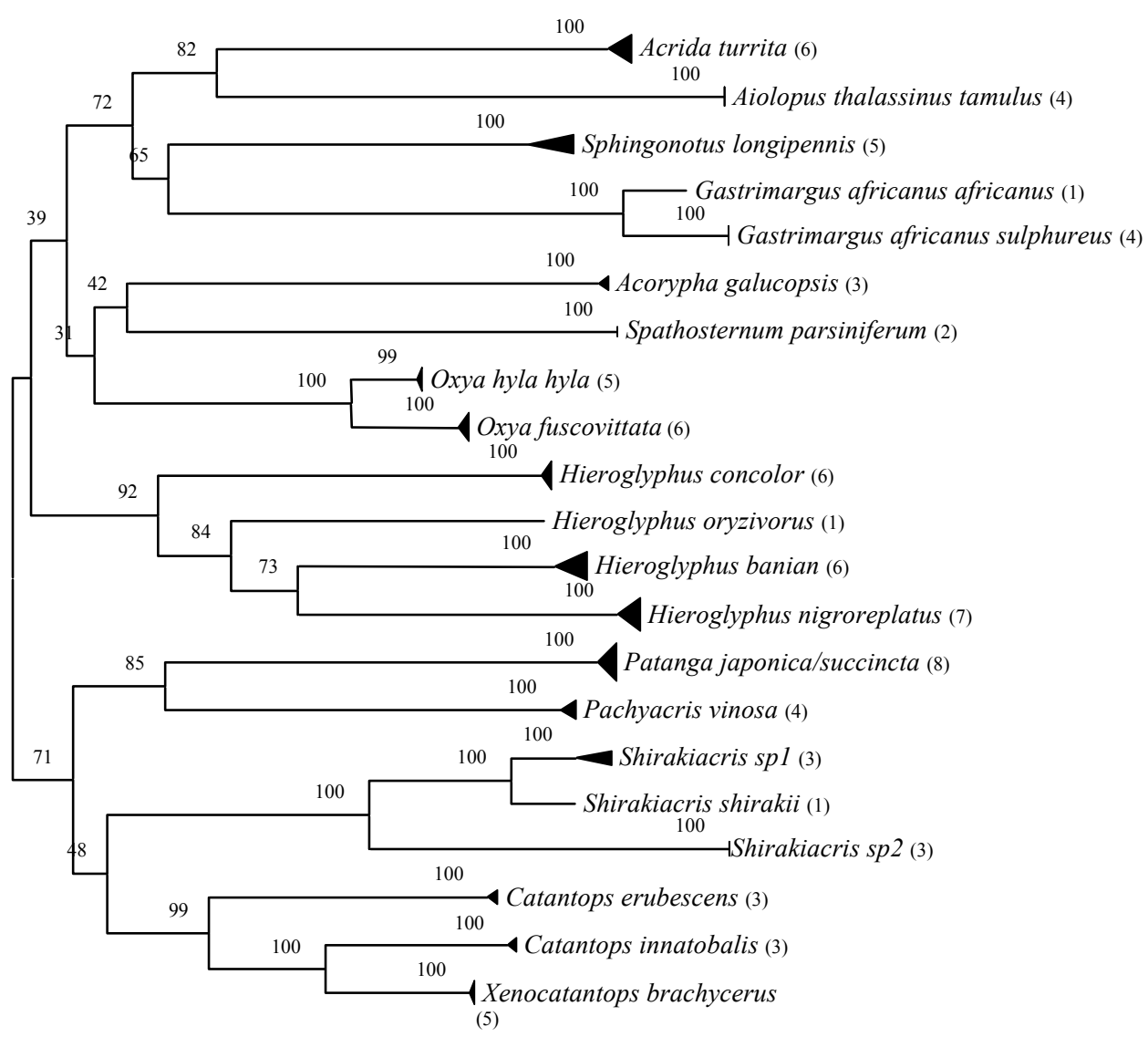

$\longmapsto 0.02$

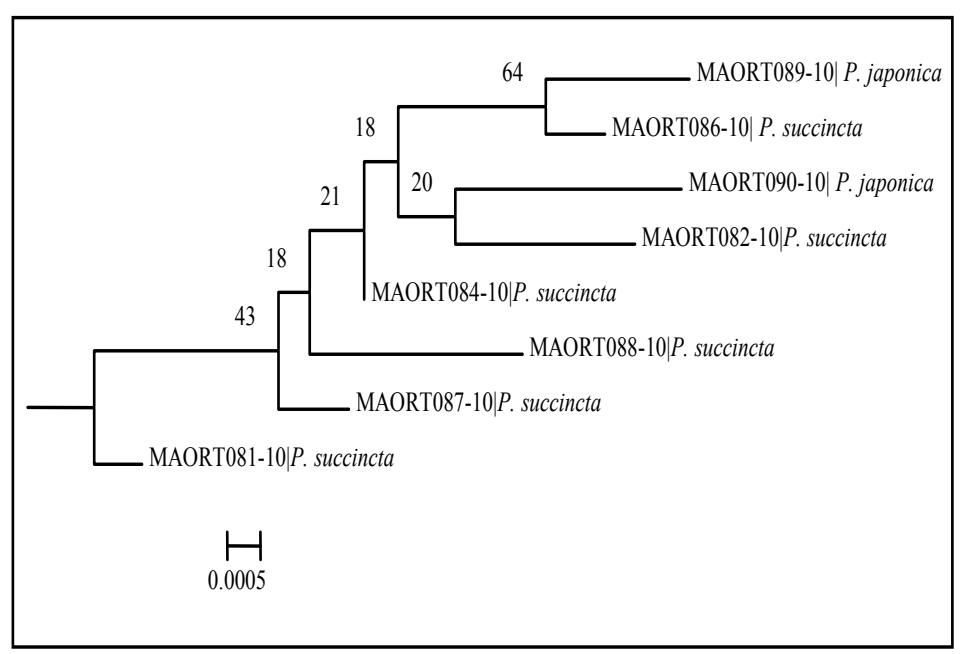

Figure 2. DNA barcode-based neighbor joining cluster analysis of species belonging to family Acrididae collected from Poonch. The tree is based on 85 sequences derived from 22 species. Bootstrap values ( 500 replicates) are shown above the branches. The tree is drawn to scale, with branch lengths in the same units as those used to infer the phylogenetic tree. Tree nodes are collapsed for each species. Numbers in brackets next to each species names represent the number of individuals analyzed. Sequence distances were computed using the K2P method and are shown as in base substitutions per site. All positions containing gaps and missing data were eliminated using pairwise deletion option. Analyses were conducted in MEGA5. Sub-tree in a box indicates branching pattern of two species, Patanga Japonica and $P$. succincta which show no pattern of genetic difference in the COI barcode region.

Aiolopus thalassinus tumulus (Fabricius, 1798) shared the barcode with conspecifics from Kenya and South
Africa. Barcodes of none of the other species from our studies matched with those from any other country in 
Table. 2 Morphologically identified species and their hosts

\begin{tabular}{|c|c|c|}
\hline Subfamily & Species & Habitat description and host plants \\
\hline \multirow{6}{*}{ Oedipodinae } & $\begin{array}{l}\text { Gastrimargus africanus africanus } \\
\text { (Saussure, 1888) }\end{array}$ & $\begin{array}{l}\text { Kalamola in grassy meadows, } 8 \text { males, } 1 \text { female, 13.ix.2010; } 3 \text { females, } \\
\text { 04.ix.2010; Khautta on grasses } 1 \text { male, 03.x.2010; Trarkhel on maize } 3 \text { males, } \\
\text { 24.vii.2010; Jandali on maize, } 1 \text { female, 08.x.2010. }\end{array}$ \\
\hline & $\begin{array}{l}\text { Gastrimargus africanus sulphureus } \\
\text { (Bie- Bienko, 1951) }\end{array}$ & $\begin{array}{l}\text { Kalamola on grasses } 3 \text { males, } 3 \text { females, 13.x.2010; } 1 \text { female, 18.ix.2010; } \\
\text { Banjosa on grasses } 2 \text { males, } 4 \text { females, 06.viii.2010; Khautta on grasses } 1 \\
\text { male, } 1 \text { female, 23.ix.2010; Trarkhel on shrubs } 3 \text { males, } 1 \text { female, 12.xi.2010. }\end{array}$ \\
\hline & $\begin{array}{l}\text { Aiolopus thalassinus tamulus } \\
\text { (Fabricius, 1798) }\end{array}$ & Hajipeer, 5 males, 4 females, 23.ix.2011 \\
\hline & Trilophidia japonica (Saussure, 1888) & $\begin{array}{l}\text { Hajipeer on wild herbs, } 6 \text { males, 23.ix.2011; Hajeera on cultivated plant nursery, } \\
3 \text { females, } 4 \text { males, 02.ix.2010 }\end{array}$ \\
\hline & Trilophidia turpis (Walker, 1870) & Hajipeer on wild herbs, 5 males, 4 females, 23.ix.2011 \\
\hline & $\begin{array}{l}\text { Sphingonotus longipennis (Saussure, } \\
\text { 1884) }\end{array}$ & Hajipeer on grassy meadows, 6 females, 5 males, 23.ix.2011 \\
\hline \multirow{2}{*}{ Acridinae } & Acrida turrita (Linne, 1758) & $\begin{array}{l}\text { Rawalakot on grasses, soybean and maize fields, } 3 \text { females, 20.x.2010; } \\
1 \text { male, 24.x.2010; Hajeera on rice field and grasses, } 4 \text { females, } 1 \text { male, } \\
\text { 24.x.2010; } 2 \text { females, } 1 \text { male, 20.x.2010. }\end{array}$ \\
\hline & Acrida gigantea (Herbst, 1786) & $\begin{array}{l}\text { Mang on grasses, } 4 \text { females, 24.x.2010; Plundari on maize fields and grasses, } \\
3 \text { females, } 4 \text { males, 24.x.2010; Rawalakot on soybean field } 1 \text { female, } 6 \text { males, } \\
\text { 25.x.2010. }\end{array}$ \\
\hline Spathosterninae & $\begin{array}{l}\text { Spathosternum parsiniferum } \\
\text { parsiniferum (Walker, 1871) }\end{array}$ & $\begin{array}{l}\text { Degwar on grasses, } 1 \text { female, 06.vii.2010; } 1 \text { female, } 3 \text { males, } 20 . i x .2010 ; 2 \\
\text { females, 20.ix.2011; } 1 \text { male, 04.ix.2011; } 1 \text { male,, } 19 . i x .2011 ; 1 \text { male, 20.ix.2011; } \\
1 \text { male, } 3 \text { females, 23.ix.2011. Khautta on maize fields and grasses, } 1 \text { female, } \\
\text { 05.viii.2011; } 1 \text { female, 04.viii.2011 }\end{array}$ \\
\hline \multirow{4}{*}{ Hemiacridinae } & $\begin{array}{l}\text { Hieroglyphus nigrorepletus (Bolivar, } \\
\text { 1912) }\end{array}$ & Hajeera on rice fields, 4 females, 6 males, 30.ix.2010 \\
\hline & Hieroglyphus banian (Fabricius, 1798) & Hajeera on rice fields, 5 males, 7 females, 20.x.2010 \\
\hline & Hieroglyphus concolor (Walker, 1870) & Hajeera on rice fields, 5 females, 7 males, 09.ix.2010 \\
\hline & Hieroglyphus oryzivorus (Carl, 1916) & Hajeera on rice fields, 5 males, 6 females, 20.x.2010 \\
\hline \multirow{4}{*}{ Oxyinae } & Oxya fuscovittata (Marschall, 1836) & $\begin{array}{l}\text { Rawalakot on grasses and soybean fields, } 20 \text { females, } 5 \text { males, 19.viii.2010; } \\
\text { Banjosa on wild shrubs, } 9 \text { females, } 2 \text { males, } 14 \text {.viii.2010; Tolipeer on wild } \\
\text { grasses, } 6 \text { females, 04.ix.2010; Jandali on maize field and grasses, } 17 \text { females, } \\
14 \text { males, } 16 . \text { viii.2010 }\end{array}$ \\
\hline & Oxya hyla hyla (Serville, 1831) & $\begin{array}{l}\text { Hajeera on grasses and rice fields, } 32 \text { females, } 2 \text { males, 20.x.2010; Baloch on } \\
\text { grasses } 12 \text { females, 07.viii.2011. }\end{array}$ \\
\hline & Oxya hyla intricata (Stål, 1861) & Hajeera on rice fields and grasses, 3 females, 7 males, 20.x.2010. \\
\hline & Oxyina bidentata (Willemse, 1925) & Rawalakot on grasses and maize field, 3 females, 4 males, 19.viii.2010. \\
\hline Calliptaminae & Acorypha glaucopsis (Walker, 1870) & $\begin{array}{l}\text { Degwar on wild grasses and herbs, } 4 \text { females, 20.ix.2009; } 1 \text { female, 04.ix.2010; } \\
2 \text { females, 06.ix.2010; } 1 \text { female, 19.ix.2010; } 3 \text { males, 04.viii.2010 (N. Nazir) }\end{array}$ \\
\hline Eyprepocnemidinae & Shirakiacris shirakii (Bolívar, 1914) & $\begin{array}{l}\text { Rawalakot on grasses and maize fields, } 2 \text { females, } 3 \text { males, 19.viii.2010; Khautta } \\
\text { on grasses and plant nursery, } 2 \text { females, 23.viii.2010; } 3 \text { males, 03.iii.2010; } \\
\text { Degwar on wild plants and grasses, } 3 \text { females, 22.viii.2010; } 2 \text { males, 03.viii.2010 } \\
\text { (N. Nazir) }\end{array}$ \\
\hline \multirow[t]{5}{*}{ Catantopinae } & Pachyacris vinosa (Walker, 1870) & $\begin{array}{l}\text { Degwar on wild grasses and herbs, } 2 \text { females, 01.x.2010; } 1 \text { female,, } 06 . v i i .2010 \text {; } \\
1 \text { female, 09.x.2010; } 2 \text { males, 10.x.2010; Khautta on maize fields and grasses, } \\
3 \text { females, 10.x.2010; Abbaspur on maize fields, plants nursery and grasses, } 2 \\
\text { females, 08.ix.2010 (N. Nazir) }\end{array}$ \\
\hline & $\begin{array}{l}\text { Paraconophyma kashmirica } \\
\text { (Mishchenko, 1950) }\end{array}$ & $\begin{array}{l}\text { Degwar on grasses and wild herbs, } 3 \text { females, 19.vii.2010; } 2 \text { males, 21.vii.2011; } \\
\text { Kalamola on wild grasses and herbs, } 3 \text { males, 15.ix.2011; } 4 \text { females, 13.ix.2010; } \\
\text { Bedori on grazing meadows, wild grasses, } 2 \text { females, 19.vii.2010; Aliabad on } \\
\text { grasses, } 2 \text { females, 12.viii.2010 (N. Nazir) }\end{array}$ \\
\hline & Catantops erubescens (Walker, 1870) & $\begin{array}{l}\text { Khautta on grasses and maize fields, } 2 \text { females, } 4 \text { males, 07.vii.2010; } 4 \text { females, } \\
\text { 20.vii.2010 (N. Nazir) }\end{array}$ \\
\hline & $\begin{array}{l}\text { Xenocatantops brachycerus } \\
\text { (Willemse, 1932) }\end{array}$ & $\begin{array}{l}\text { Hajipeer on wild flower plants, } 3 \text { females, } 2 \text { males, 23.ix.2011; Halan Shumali on } \\
\text { wild plants, } 1 \text { female, } 5 \text { males, 23.ix.2011; Bagh on grasses, } 2 \text { females, } 1 \text { male, } \\
\text { 23.ix.2011 (N. Nazir) }\end{array}$ \\
\hline & Catantops innatobalis (Walker, 1871) & Khautta on wild flowers and grasses, 4 females, 6 males, 07.vii.2010 (N. Nazir) \\
\hline \multirow[t]{2}{*}{ Cyrtacanthacridinae } & Patanga succincta (Johannson, 1763) & $\begin{array}{l}\text { Rawalakot on grasses and soybean field, } 3 \text { females, } 2 \text { males, 03.ix.2010; } \\
\text { Bagh on grasses } 4 \text { females, 23.ix.2011; Trarkhel on maize fields, } 2 \text { females, } 1 \\
\text { male, 16.x.2010; Jandali on dry residues of maize plants, } 6 \text { females, } 4 \text { males, } \\
\text { 18.x.2010 (N. Nazir) }\end{array}$ \\
\hline & Patanga japonica (Bolivar, 1898) & $\begin{array}{l}\text { Rawalakot } 4 \text { females, } 1 \text { male, 03.ix.2010; Trarkhel } 5 \text { females, } 3 \text { males, 16.x.2010. } \\
\text { (N. Nazir). }\end{array}$ \\
\hline
\end{tabular}




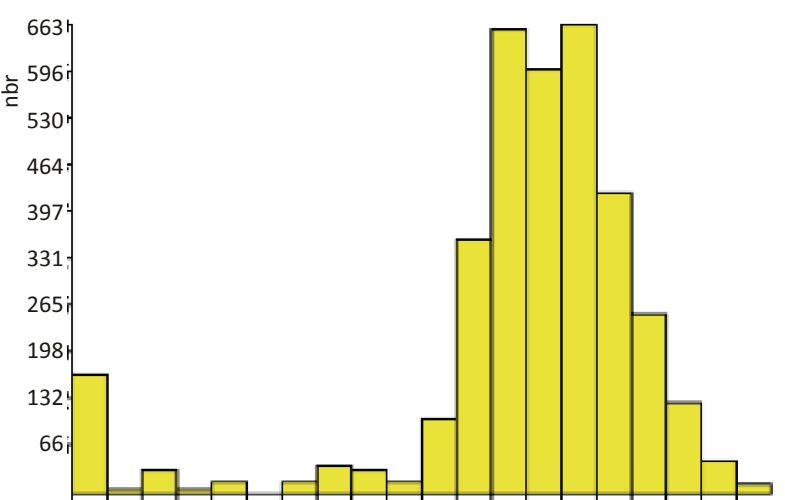

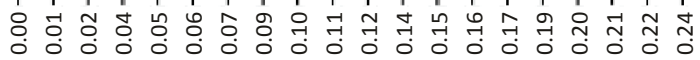

(A) Histogram of intraspecific distances

Dist. value

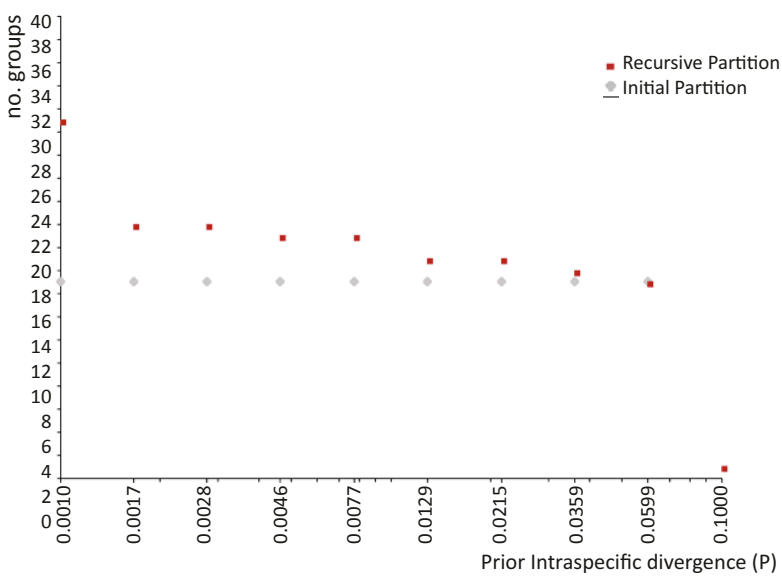

(B) Partition analysis.

Figure 3. Pairwise distance divergence analysis of Acridid grasshopper species as performed by ABGD.

\section{BOLD or NCBI databases.}

Cluster analysis of the barcode data showed that 18 of the 21 species included in the dataset formed distinct and non-overlapping monophyletic clusters (Fig. 2). Tree nodes for each morphological species with multiple specimens were collapsed which appear as vertical lines or triangles in the tree indicating the level of intraspecific divergence. Two species, Patanga japonica (Bolivar, 1898) and Patanga succincta (Johannson, 1763) shared the same cluster on the dendrogram. The subtree (Fig. 2A) indicates the minor genetic distances among the specimens of these two species but with no clear pattern of species grouping. Specimens of the species, Eyprepocnemis shiriaki produced three separate clusters with significant bootstrap support (100\%) indicating that the species is a complex of at least three species (Fig. 2). The species Gastrimargus africanus is represented by two subspecies, G. africanus africanus (Saussure, 1888) and Gastrimargus africanus sulphureus (Bie- Bienko 1951). Both the subspecies made monophyletic clusters with strong bootstrap support (Fig. 2). Pachyacris vinosa lies on the same branch as on the Patanga succincta (Johannson, 1763) and Patanga japonica (Bolivar, 1898) while according to Orthoptera Specie File (OTS) Patanga succincta (Johannson, 1763) and Patanga japonica (Bolivar, 1898) are under the subfamily Cyrtacanthacridinae (Kirby, 1902) and Pachyacris vinosa (Walker, 1870) under the subfamily Catantopinae BieBienko \& Mischenko (1951). According to barcoding results both of them share the same genus and subfamily which supports Bie-Bienko \& Mischenko (1951) who kept Pachyacris vinosa (Walker, 1870), Patanga succincta (Johannson, 1763) and Patanga japonica (Bolivar, 1898) under the same subfamily Catantopinae.

The distance data and the groups produced by recursive and initial partitions generated by $A B G D$ are presented in Fig. 3A and 3B. In the dataset 18 species are represented by two or more than two specimens. The distributions of distances show a gap between the intraspecific and the interspecific distances (Fig. 3A). The partitions analysis shows the presence of 19 groups by recursive partition at a divergence level of $2.15 \%$ in the dataset (Fig. 3B).

\section{DISCUSSIONS}

The variability in the genus Gastrimargus was found in two subspecies and when they were barcoded their sequence data show a considerable variation among the two morpho subspecies. Some of the species were collected from a very low altitude to very higher altitudes showing a wide range of distribution. In the present study 26 species of family Acrididae were identified and subjected to DNA barcoding made comparisons with the nucleotide data among species and phylogenetic analysis performed. Out of 26 species, barcoding results of 21 species were obtained. The remaining five species either did not yield amplification or the sequences were not of good quality/were contaminated. Among these sequenced species morphologically identified two same subspecies of genus Gastrimargus shown in the phylogenetic tree represents a lot of variation which requires further taxonomic expertise to resolve this confusion. Similarly, two species of genus Patanga also require taxonomic expertise and it is in the process of removal by the taxonomist first author and co-authors. Nucleotide data of the gene sequenced in these studies did not match perfectly with any of the other grasshopper species in the Gene Bank. Similarly, there were significant nucleotide variations among all the 
sequenced genes of the 18 species. The DNA barcode region of $\mathrm{COI}\left(\mathrm{COI}-5^{\prime}\right)$ showed significant nucleotide differences among grasshopper species and came out as a promising region to be used for grasshopper species identification. The phylogenetic analysis based on the barcode region of $\mathrm{COI}$ also provided better relationships among various grasshopper species. DNA barcoding is a new phenomenon and is not only being used to identify species but is also being used to study species relationships and to investigate genetic diversities among insect populations (Mondal et al. 1999; Hajibabaei et al. 2006; Emery et al. 2009; Ashfaq et al. 2011). In conclusion, the use of nucleotide data from the barcode region of $\mathrm{COI}$ supported the grasshoppers, identifications and phylogenetic relationships performed on the basis of morphological characters. The nucleotide data, however, could not be used to make comparisons with other such sequences in the gene bank databases as sequences from the same region of $\mathrm{COI}$ were not available in the gene bank. This shows the limitation of the use of DNA data for species identification. Sequences produced from the grasshopper species in the current studies and their submission in the gene bank database will be a good addition to the sequence database as well as to the barcode reference library.

\section{REFERENCES}

Ashfaq, M., J. Ara, A.R. Noor, P.D.N. Hebert \& S. Mansoor (2011). Molecular phylogenetic analysis of a scale insect (Drosicho mangiferae; Hemiptera: Monophlebidae) infesting mango orchards in Pakistan. European Journal of Entomology 108(4): 553-559.

Azim, M.N. \& S.A. Reshi (2010). Taxonomic notes on the tribe Acridin Latreille (Acridinae: Acrididae: Orthoptera) of Kashmir, India. Acta Zoológica Mexicana (nueva serie) 26(1): 219-222.

Bie-Bienko, G.Y. \& L.L. Mischenko (1951). Locust and Grasshoppers of USSR and Adjacent Countries. Pt I \& II, Monson, Jerusalem, 691pp.

Brust, L.M. (2008). Taxonomy and distribution of Acridid grasshoppers in Nebraska and effect of temperature and immersion on grassland pests. PhD Thesis, University of Nebraska.

Burns, J.M., D.H. Janzen, M. Hajibabaei, W. Hallwachs, P.D.N. Hebert (2007). DNA barcodes of closely related (but morphologically and ecologically distinct) species of skipper butterflies (Hesperiidae) can differ by only one to three nucleotides. Journal of the Lepidopterists Society 61: 138-153.

Chapco, W. \& G. Litzenberger (2002). A molecular phylogenetic study of two relict species of melanopline grasshoppers. Genome 45(2): 313-318; http://dx.doi.org/10.1139/g01-156

Chapco, W. \& G. Litzenberger (2003). A molecular phylogenetic analysis of the grasshopper genus Melanoplus Stål (Orthoptera: Acrididae) - an update. Journal of Orthoptera Research 11(1): 1-9; http://dx.doi.org/10.1665/1082-6467(2002)011[0001:AMPAOT]2. $0 . \mathrm{CO} ; 2$

Colgan, D.J. (1991). Phylogenetic studies of acridoid grasshoppers comparing 2n2- and 4-base recognizing endonucleases. Journa of Evolutionary Biology 4(4): 575-591; http://dx.doi.org/10.1046/ j.1420-9101.1991.4040575.x

Deng, J., F. Yu, T.X. Zhang, H.Y. Hu, C.D. Zhu, S.A. Wu \& Y.Z. Zhang (2012)
DNA barcoding of six Ceroplastes species (Hemiptera: Coccoidea: Coccidae) from China. Molecular Ecology Resources 12(5): 791-796; http://dx.doi.org/10.1111/j.1755-0998.2012.03152.x

Drish, V.M. (1961). A preliminary revision of the families and subfamilies of Acridoidae (Orthoptera: Insecta). Bulletin of British Museum (Natural History) Entomology 10: 351-419.

Eades, D.C., D. Otte, M.M. Cigliano \& H. Braun (2011). Orthoptera Species File. Version 5.0/5.0. [may 2013]. <http://Orthoptera. SpeciesFile.org>.

Emery, V.J., L.J. Eckert \& G. Christopher (2009). Combining DNA barcoding and morphological analysis to identify specialist floral parasites (Lepidoptera: Coleophoridae: Momphinae: Mompha). Molecular ecology Resource 9(s1): 217-223; http://dx.doi. org/10.1111/j.1755-0998.2009.02647.x

Fletcher, J.B. (1919). Annotated list of Indian crop pest. Report of Proceedings of $3^{\text {rd }}$ Entomological Meeting, Pusa, 1: 306pp.

Guralnick, R. \& A. Hill (2009). Biodiversity informatics: automated approaches for documenting global biodiversity patterns and processes. Bioinformatics 25(4): 421-428; http://dx.doi. org/10.1093/bioinformatics/btn659

Hajibabaei, M., D.H. Janzen, J.M. Burns, W. Hallwachs \& P.D.N. Hebert (2006). DNA barcodes distinguish species of tropical Lepidoptera. Proceedings of National Academy of Science 103(4): 968-971; http://dx.doi.org/10.1073/pnas.0510466103

Hebert, P.D.N., A. Cywinska, S.L. Ball \& J.R. deWaard (2003). Biological identifications through DNA barcodes. Proceedings of Royal Society, London, B. 270(1512): 313-321; http://dx.doi.org/10.1098/ rspb.2002.2218

Hebert, P.D.N., M.Y. Stoeckle, T.S. Zemlak \& C.N. Francis (2004). Identification of birds through DNA barcodes. PLoS Biology 2: 16571663.

Ivanova, N.V., J.R. deWaard, P.D.N. Hebert (2006). An inexpensive, automation-friendly protocol for recovering high-quality DNA. Molecular Ecology Notes 6(4): 998-1002; http://dx.doi. org/10.1111/j.1471-8286.2006.01428.x

Janzen, D.H., M. Hajibabaei, J.M. Burns, W. Hallwachs, E. Remigio \& P.D.N. Hebert (2005). Wedding biodiversity inventory of a large and complex Lepidoptera fauna with DNA barcoding. Philosophical Transactions of Royal Society B: Biological Sciences 360(1462): 1835-1845; http://dx.doi.org/10.1098/rstb.2005.1715

Janzen, D.H., W. Hallwachs, P. Blandin, J.M. Burns, J.M. Cadiou, I. Chacon, T. Dapkey, A.R. Deans, M.E. Epstein, B. Espinoza, J.G. Franclemont, W.A. Haber, M. Hajibabaei, J.P.W. Hall, P.D.N. Hebert, I.D. Gauld, D.J. Harvey, A. Hausmann, I.J. Kitching, D. Lafontaine, J.F. Landry, C. Lemaire, J.Y. Miller, J.S. Miller, L. Miller, S.E. Miller, J. Montero, E. Munroe, S.R. Green, S. Ratnasingham, J.E. Rawlins, R.K. Robbins, J.J. Rodriguez, R. Rougerie, M.J. Sharkey, M.A. Smith, M.A. Solis, J.B. Sullivan, P. Thiaucourt, D.B. Wahl, S.J. Weller, J.B. Whitfield, K.R. Willmott, D.M. Wood, N.E. Woodley \& A.J. Wilson (2009). Integration of DNA barcoding into an ongoing inventory of complex tropical biodiversity. Molecular Ecology Resources 9: 1-26; http://dx.doi.org/10.1111/j.1755-0998.2009.02628.x

Jarman, S.N. \& N.G. Elliott (2000). DNA evidence for morphological and cryptic Cenozoic speciations in the Anaspididae, 'living fossils' from the Triassic. Journal of Evolution Biology 13(4): 624-633; http://dx.doi.org/10.1046/j.1420-9101.2000.00207.x

Ketmaier, V., H. Stuckas, J. Hempel, I. Landeck, M. Tobler, M. Plath \& R. Tiedemann (2010). Genetic and morphological divergence among Gravel Bank Grasshoppers, Chorthippus pullus (Acrididae), from contrasting environments. Organism Diversity and Evolution 10(5): 381-395; http://dx.doi.org/10.1007/s13127-010-0031-1

Kirby, W.F. (1914). Orthoptera (Acrididae). Fauna of British India including Ceylon and Burma. Taylor and Francis, London, 276pp.

Mahmood, K. (1995). Taxonomic studies of Acridoidea (Orthoptera) of Azad Jammu and Kashmir. PhD Thesis. Department of Entomology, University of Agriculture Faisalabad, Pakistan.

Mahmood, K. \& M. Yousaf (1999). New records of Oedipodinae (Acrididae: Orthoptera) from Azad Jammu and Kashmir with the description of a new species. Journal of Orthoptera Research 3: 
271-275.

Mahmood, K. \& M. Yousaf (2000). Taxonomic studies on Pyrgomorphidae and Catantopinae (Acridiodea; Orthoptera) from Azad Jammu and Kashmir. Pakistan Journal of Biological Sciences 3(11): 1914-1916.

Mahmood, K. \& U. Rizwan (2002). Grasshoppers species composition and distribution pattern in District Poonch, Azad Jammu and Kashmir, Pakistan (conference paper).

Mahmood, K., Y. Mohammad \& K. Abdul (2002). Taxonomic study of some Catantopinae (Acrididae: Orthoptera) from Azad Jammu and Kashmir. Pakistan Journal of Zoology 34(3): 233-237.

Mahmood, K. \& W. Shah (2003). New records of Eyprepocnemidinae (Acrididae: Orthoptera) from Azad Jammu and Kashmir. Pakistan Journal of Arid Agriculture 6(1): 25-27.

Mahmood, K., K. Abbas \& W.H. Shah (2004). A Preliminary Study of grasshoppers (Acrididae: Orthoptera) of Baltistan, Azad Jammu \& Kashmir, Pakistan. Pakistan Journal of Zoology 36(1): 21-25.

Mason, J.B. (1973). A revision of the genera Hieroglyphus Krauss, Parahieroglyphus Carl and Hieroglyphodes Uvarov (Orthoptera: Acridiodea). Bulletin of British Museum (Natural History) Entomology 28(7): 509-560.

Matz, M.V. \& R. Nielsen (2005). A likelihood ratio test for species membership based on DNA sequence data. Philosophical Transactions of Royal Society B: Biological Sciences 360(1462): 1969-1974; http://dx.doi.org/10.1098/rstb.2005.1728

Mondal, S.K., A.K. Hazra \& S.K. Tandon (1999). Studies on taxonomy, biology and ecology of grasshoppers infesting field crops and vegetables with notes on nymphal taxonomy of some species in West Bengal. Records of the Zoological Survey of India. Occasional Paper 173: 1-178.

Mukha, D., W.M. Brian \& C. Schal (2001). Evolution and phylogenetic information content of the ribosomal DNA repeat unit in the Blattodea (Insecta). Journal of Insect Biochemistry and Molecular Biology 32(9): 951-960; http://dx.doi.org/10.1016/S09651748(01)00164-3

Puillandre, N., A. Lambert, S. Brouillet \& G. Achaz (2012). ABGD, automated barcode gap discovery for primary species delimitation. Molecular Ecology 21(8): 1864-1877; http://dx.doi.org/10.1111/ j.1365-294X.2011.05239.x

Reshi, S.A. \& N. Azim (2008). Studies on some aspects of biodiversity of Cyrtacanthacridini (Orthoptera: Acrididae) of Kashmir, Himalayas. Annals of Plant Protection Sciences 16(2): 393-395
Ritchie, J. (1982). A taxonomic Revision of the genus Gastrimargus Saussure (Orthoptera: Acrididae). Bulletin of British Museum (Natural History) Entomology 44: 293-329.

Rowell, C.H.F. \& P.K. Flook (2004). A dated molecular phylogeny of the Proctolabinae (Orthoptera, Acrididae), especially the Lithoscirtae, and the evolution of their adaptive traits and present biogeography. Journal of Orthoptera Research 13(1): 35-56; http://dx.doi. org/10.1665/1082-6467(2004)013[0035:ADMPOT]2.0.CO;2

Scotland, R.W., R.G. Olmstead \& J.R. Bennett (2003). Phylogeny reconstruction: The role of morphology. Systematic Biology 52(4): 539-548.

Song, H. \& J.W. Wenzel (2007). Phylogeny of bird-grasshopper subfamily Cyrtacanthacridinae (Orthoptera: Acrididae) and the evolution of locust phase polyphenism. Cladistics 24(4): 515-542; http://dx.doi.org/10.1111/j.1096-0031.2007.00190.x

Suhail, A. (1994). Taxonomic studies on Acridoidea (Orthoptera) of Pakistan. PhD Thesis. Department of Agriculture Entomology, University of Agriculture Faisalabad, Pakistan, 343pp.

Tamura K., D. Peterson, N. Peterson, G. Stecher, M. Nei \& S. Kumar (2011). MEGA5: Molecular evolutionary genetics analysis using maximum likelihood, evolutionary distance, and maximum parsimony methods. Molecular Biology Evolution 28(10): 27312739; http://dx.doi.org/10.1093/molbev/msr121

Thompson, J.D., D.G. Higgins \& T.J. Gibson (1994). ClustalW: improving the sensitivity of progressive multiple sequence alignment through sequence weighting, position-specific gap penalties and weight matrix choice. Nucleic Acids Research 22(22): 4673-4680; http:// dx.doi.org/10.1093/nar/22.22.4673

Valentini, A., F. Pompanon \& P. Taberlet (2009). DNA barcoding for ecologists. Trends in Ecology and Evolution 24(2): 110-117; http:// dx.doi.org/10.1016/j.tree.2008.09.011

Watts, J.G., E.W. Huddleston \& J.C. Owens (1982). Rangeland entomology. Annual Review of Entomology 27: 283-311; http:// dx.doi.org/10.1146/annurev.en.27.010182.001435

Wilson, K.H. (1995). Molecular biology as a tool for taxonomy. Clinical Infectious Diseases 20: 192-208.

Xiao, J.H., N.H. Wang, Y.W. Li, R.W. Murphy, D.G. Wan, L.M. Niu, H.Y. Hu, Y.G. Fu \& D.W. Huang (2010). Molecular approaches to identify cryptic species and polymorphic species within a complex of community of Fig Wasps. PLOS ONE 5: e15067; http://dx.doi. org/10.1371/journal.pone.0015067 